Energy Research Journal 1 (2): 104-110, 2010

ISSN 1949-0151

(C) 2010 Science Publications

\title{
Mathematical Model of the Optimum Heat Pipe Heat Exchanger for a Condenser of Vapor-Compression Refrigeration Cycle
}

\author{
P. Yeunyongkul, P. Sakulchangsatjatai and P. Terdtoon \\ Department of Mechanical Engineering, Faculty of Engineering, \\ Chiang Mai University, Chiang Mai, Thailand, 50200
}

\begin{abstract}
Problem statement: This study theoretically investigated applying heat pipe as a heat exchanger in the condenser of vapor compression refrigeration system for sustainable well-being. Splittype air conditioner for residential propose was considered. To reduce pressure drop and recover heat from the condensing process of the refrigeration cycle, this investigation tried to use Closed Loop Oscillating Heat Pipe (CLOHP) instead of the conventional condenser in split-type air conditioner. Approach: The system was single stage with reciprocating compressor which operated at steady state. The refrigerating capacity was $12,500 \mathrm{Btu} \mathrm{h}^{-1}$ and refrigerant was R22. The vapor compression refrigeration system was simulated to determine effect of mass flow rate of refrigerant on various parameters; such as refrigerating capacity, compressor power, heat rejection of condenser and Coefficient of Performance. Results: It was found that, at the normal operating and 3,663 W of the cooling load, mass flow rate of refrigerant, compressor power, heat rejection of condenser and Coefficient of Performance were $0.031 \mathrm{~kg} \mathrm{sec}^{-1}, 1,174 \mathrm{~W}, 4,837 \mathrm{~W}$ and 3.1, respectively. In addition, an increase in evaporating temperature or a decrease in condensing temperature results in increase of refrigerating capacity. CLOHP heat exchanger was simulated to predict optimum sizing on the basis of thermo-economical method. It was found that the optimum sizing of CLOHP heat exchanger with R123 as working fluid were; $0.1 \mathrm{~m}$ of evaporator section Length $\left(\mathrm{L}_{\mathrm{e}}\right), 0.1 \mathrm{~m}$ of condenser section Length $\left(\mathrm{L}_{\mathrm{c}}\right), 2.03 \mathrm{~mm}$ of inner Diameter $\left(\mathrm{D}_{\mathrm{i}}\right)$ and 218 turns of number of turn $(\mathrm{N})$. The optimum sizing when water was used as working fluids were $0.1 \mathrm{~m}$ of $\mathrm{L}_{\mathrm{e}}, 0.1 \mathrm{~m}$ of $\mathrm{L}_{\mathrm{c}}, 2.03 \mathrm{~mm}$ of $\mathrm{D}_{\mathrm{i}}$ and 176 of $\mathrm{N}$. Finally, the optimum sizing when ethanol was used as working fluids were $0.1 \mathrm{~m}$ of $\mathrm{L}_{\mathrm{e}}, 0.1 \mathrm{~m}$ of $\mathrm{L}_{\mathrm{c}}$, $2.03 \mathrm{~mm}$ of $\mathrm{D}_{\mathrm{i}}$ and 243 of $\mathrm{N}$. Moreover, net saving of R123, water and ethanol systems at the optimum size were 9,095, 9,117 and 9,082 USD, respectively. Conclusion: The optimum $A_{H E}, N, L_{e}, L_{c}$ and $D_{i}$ are $0.45 \mathrm{~m}^{2}, 176$ turns, $0.1,0.1$ and $0.00203 \mathrm{~m}$, respectively.
\end{abstract}

Key words: Heat pipe heat exchanger, vapor compression refrigeration, closed loop oscillating heat pipe, optimum, thermo-economical method

\section{INTRODUCTION}

Refrigeration is the process of moving heat from one location to another by means of refrigerant in a closed refrigeration cycle. The refrigeration is developed and applied to use in various purposes such as food industry, chemical industry and air conditioning for sustainable well-being. The air conditioning is commonly used in a wide range for residence, building, office and hotel. The most of air conditioner types for this purpose call "split type" that is divided to two parts are fan coil unit and condensing unit which the fan coil unit is located inside the room and another one is located outside the room. The split type air conditioner based on the vapor compression refrigeration is shown in Fig 1. It was considered with two disadvantages. Firstly, when refrigerant flows inside small tube in the condenser, large pressure drop which is proportional to compressor power can be obtained.

Whenever, the system operated with high compressor power, the COP decreases. Secondly, since the refrigerant has to condenses after passing through condenser, large amount of wasted heat losses to surrounding occurs in this process. To reduce pressure drop and recover heat from the condensing process, this investigation tries to apply Closed Loop Oscillating Heat Pipes (CLOHP) instead of the conventional condenser in split-type air conditioner as shown in Fig. 2. The CLOHP is heat transfer device with very high thermal conductivity, high thermal response and can operate at

Corresponding Author: P. Yeunyongkul, Department of Mechanical Engineering, Faculty of Engineering,

Chiang Mai University, Chiang Mai, Thailand, 50200 Tel: 66-5394-4144/ext. 911 Fax: 66-5322-6014 
low temperature difference. Many researchers study the effect of working fluid types and flow rate on thermal effectiveness on CLOHP for air-conditioning. It is found from the study that, the thermal effectiveness decreases when the working fluid changes from R134a to MP39 or increase the mass flow rate of cooling fluid (Kammuang-Lue et al., 2006). The CLOHP with check valves (CLOHPCV hereafter) has been applied for reducing relative humidity in drying system and it can reduce relative humidity and achieve energy thrift (Meena et al., 2007). Heat rejected from a split-type residential air conditioner was recovered for clothes drying in residential buildings. The results indicated that the system was effective for its reasonably short drying duration and high energy use efficiency during air conditioning seasons (Shiming and Han, 2004). From the previous literatures it can be seen that, there are no substantial studies on applying the CLOHP as a condenser in the refrigeration system to reduce pressure drop and recover heat from the condensing process.

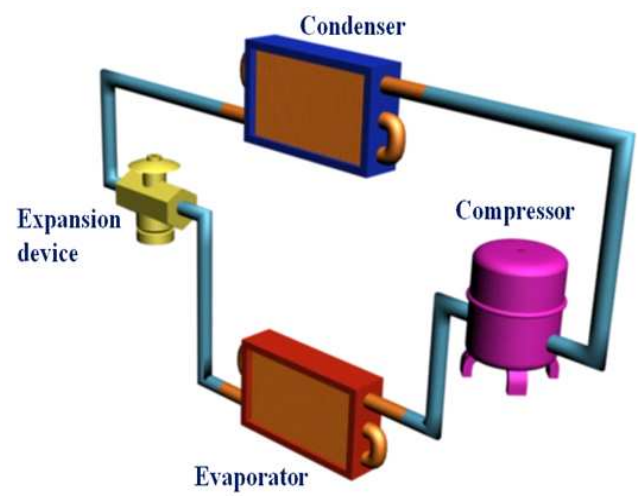

Fig. 1: The conventional vapor compression system

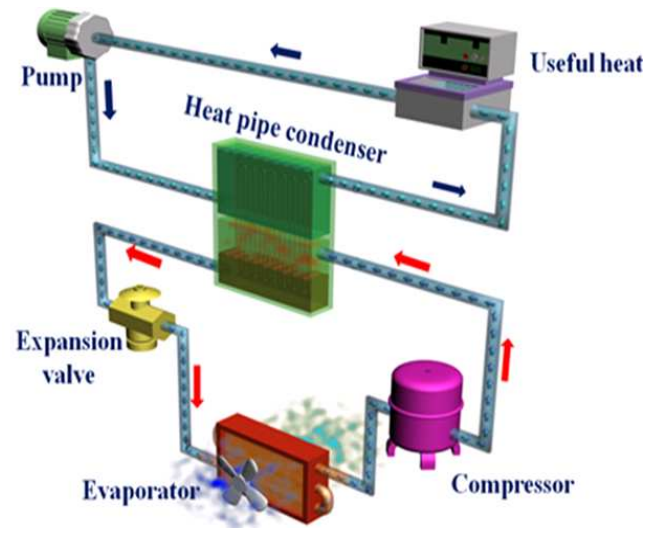

Fig. 2: The heat pipe condenser for vapor compression system
Therefore, this study aims to investigate the mathematical model to predict the optimum sizing of the closed loop pulsating heat pipe condenser instead of the conventional condenser in the refrigeration system. Our optimization technique will be on the basis of a thermo-economical method or $\mathrm{P}_{1}-\mathrm{P}_{2}$ method (Soylemez, 2000; Soylemez, 2003; Soylemez, 2004).

\section{MATERIALS AND METHODS}

\section{Mathematical model:}

The conventional refrigeration model: A schematic diagram of the conventional vapor compression refrigeration system is shown in Fig. 1 and its operating cycle is shown in Fig. 3. The system consists of the four major components are compressor, condenser, expansion device or capillary tube and evaporator. The mathematical model of each component can be described as follow.

Compressor model: The compressor model is obtained by Chan and $\mathrm{Yu}$ (2002) as in Eq. 1 to compute the compressor power input and as in Eq. 2 for the refrigerant mass flow rate. The work input to the refrigerant during the compression process can be calculate from Eq. 3. The isentropic efficiency of the compressor was given by Eq. 4 and the compressor efficiency can be calculated from Eq. 5:

$$
\dot{\mathrm{w}}_{\text {comp }}=\frac{\dot{\mathrm{m}}_{\text {ref }} \mathrm{w}_{\text {in }}}{\eta_{\text {isen }} \eta_{\mathrm{c}}}
$$

Where:

$$
\begin{array}{ll}
\dot{\mathrm{W}}_{\text {comp }} & =\text { Compressor power input }(\mathrm{W}) \\
\dot{\mathrm{m}}_{\text {ref }} & =\text { Refrigerant mass flow rate }\left(\mathrm{kg} \mathrm{sec}^{-1}\right) \\
\mathrm{w}_{\text {in }} & =\text { Work of compression process }\left(\mathrm{J} \mathrm{sec}^{-1}\right) \\
\eta_{\text {isen }} & =\text { Isentropic efficiency of compressor } \\
\eta_{\mathrm{c}} & =\text { Efficiency of compressor }
\end{array}
$$

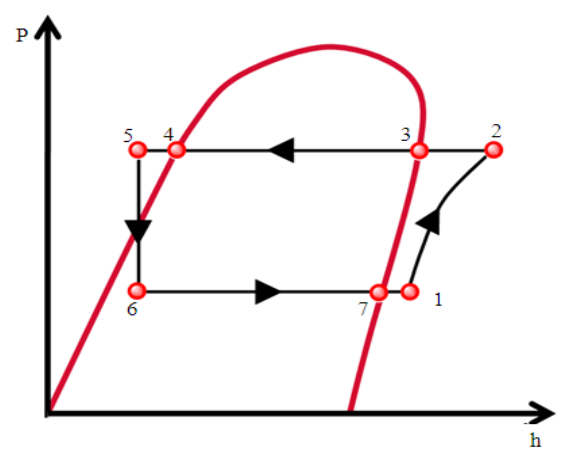

Fig. 3: The P-h diagram of the conventional vapor compression refrigeration system 
Energy Rec. J. 1 (2): 104-110, 2010

$\dot{\mathrm{m}}_{\mathrm{ref}}=\frac{\mathrm{V}_{\mathrm{P}} \eta_{\mathrm{v}}}{\mathrm{v}_{1}}$

Where:

$\mathrm{V}_{\mathrm{P}}=$ Volume of compressor $\left(\mathrm{m}^{3} \mathrm{sec}^{-1}\right)$

$\eta_{\mathrm{v}}=$ Volumetric efficiency of compressor

$\mathrm{v}_{1}=$ Specific volume at compressor inlet $\left(\mathrm{m}^{3} \mathrm{~kg}^{-1}\right)$

$\mathrm{w}_{\text {comp }}=\mathrm{P}_{\mathrm{e}} \mathrm{V}_{1} \frac{\mathrm{n}-1}{\mathrm{n}}\left(\mathrm{CR} \mathrm{R}^{\frac{\mathrm{n}-1}{\mathrm{n}}}-1\right)$

$\eta_{\text {isen }}=0.73-0.1 C R-0.026 \mathrm{CR}^{2}+0.0017 \mathrm{CR}^{3}$

where, $\mathrm{CR}$ is compression ratio:

$\eta_{\mathrm{c}}=1.1 \eta_{\mathrm{v}}$

Capillary tube model: The capillary tube model employed the equation from ASHRAE (1997) handbook. The Buckingham-Pi theorem was applied to determine the physical factors and fluid properties that affect capillary tube flow. This results in a group of eight dimensionless $\mathrm{Pi}$ terms. The capillary tube is assumed to be adiabatic and refrigerant in entering state can be subcooled or a mixture of liquid and vapor. The procedure for determining $\pi_{8}$ may be found in ASHRAE (1997):

$\dot{\mathrm{m}}_{\text {ref }, \text { cap }}=\pi_{8} \mathrm{~d}_{\text {cap }} \mu_{\mathrm{f}}$

Where:

$\dot{\mathrm{m}}_{\text {ref }, \text { cap }}=$ Refrigerant mass flow rate out from capillary tube $\left(\mathrm{kg} \mathrm{sec}^{-1}\right)$

$\pi_{8} \quad=$ A group of eight dimensionless Pi terms

$\mathrm{d}_{\text {cap }}=$ Diameter of capillary tube $(\mathrm{m})$

$\mu_{\mathrm{f}} \quad=$ Liquid viscosity of refrigerant $(\mathrm{Pa} \cdot \mathrm{s})$

Equation 6 is used to compute the refrigerant mass flow rate to compare with the value obtained from Eq. 2 until agreement within a specified tolerance is achieved as shown in Fig 4.

Evaporator model: In this study, the refrigerating capacity is equal to the cooling load in the air conditioning room. In this case, the refrigerating capacity is 3,663 watt $\left(12,500 \mathrm{Btu} \mathrm{h}^{-1}\right)$ or a result of calculation based on Eq. 7:

$\dot{\mathrm{Q}}_{\mathrm{e}}=\dot{\mathrm{m}}_{\mathrm{ref}}\left(\mathrm{h}_{1}-\mathrm{h}_{6}\right)$
Where:

$\dot{\mathrm{Q}}_{\mathrm{e}}=$ Refrigerating capacity (W)

$\mathrm{h}_{1}=$ Enthalpy at compressor inlet $\left(\mathrm{J} \mathrm{kg}^{-1}\right)$

$\mathrm{h}_{6}=$ Enthalpy at evaporator inlet $\left(\mathrm{J} \mathrm{kg}^{-1}\right)$

Condenser model: The heat rejection in the condenser can be calculated from Eq. 8 and 9:

$\dot{\mathrm{Q}}_{\mathrm{c}}=\dot{\mathrm{m}}_{\mathrm{ref}}\left(\mathrm{h}_{2}-\mathrm{h}_{5}\right)$

Where:

$\dot{\mathrm{Q}}_{\mathrm{c}}=$ Heat rejection in condenser $(\mathrm{W})$

$\mathrm{h}_{2}=$ Enthalpy at compressor exit $\left(\mathrm{J} \mathrm{kg}^{-1}\right)$

$\mathrm{h}_{5}=$ Enthalpy at condenser exit $\left(\mathrm{J} \mathrm{kg}^{-1}\right)$

$\dot{\mathrm{Q}}_{\mathrm{c}}=\dot{\mathrm{Q}}_{\mathrm{e}}+\dot{\mathrm{W}}_{\text {comp }}$

The heat pipe condenser model: The heat pipe condenser will be designed firstly by the the total internal resistance principle and, then, by thermoeconomical method. This method, is widely used to determine the optimum sizing of the heat exchanger to recover heat. Original results are presented by Soylemez (2000; 2003; 2004). The net savings function for waste heat recovery from a heat pipe condenser can be written by Eq. 10:

$\mathrm{S}=\mathrm{P}_{1} \mathrm{C}_{\mathrm{E}} \mathrm{HQ}-\mathrm{P}_{2}($ Fist $\cos \mathrm{t})$

Where:

$\mathrm{S}$ = Savings gained from waste heat recovery (USD)

$\mathrm{P}_{1}=$ Ratio of life cycle energy cost saving to first year energy cost saving

$\mathrm{P}_{2}=$ Ratio of life cycle expenditures incurred because of additional capital investment to initial investment

$\mathrm{C}_{\mathrm{E}}=$ Cost of energy recovered by heat pipe heat exchanger (baht $\mathrm{W} \cdot \mathrm{h}^{-1}$ )

$\mathrm{H}=$ Annual time of operation $\left(\mathrm{h}\right.$ year ${ }^{-1}$ )

$\dot{\mathrm{Q}}=$ Heat recovered by heat pipe heat exchanger $(\mathrm{W})$

if $\mathrm{i}=\mathrm{d}$, the economic parameter, $\mathrm{P}_{1}$ can be evaluated in Eq. 11. However, if $\mathrm{i} \neq \mathrm{d}$, the value of $\mathrm{P}_{1}$ can be calculated by Eq. 12:

$\mathrm{P}_{1}=\frac{\mathrm{N}_{\mathrm{T}}}{1+\mathrm{i}}$

Where:

$\mathrm{N}_{\mathrm{T}}=$ Technical life of heat pipe heat exchanger (year)

$\mathrm{I}=$ Energy price rate 
Energy Rec. J. 1 (2): 104-110, 2010

$$
\mathrm{P}_{1}=\left[\frac{1}{\mathrm{~d}-\mathrm{i}}\right]\left[1-\left(\frac{1+\mathrm{i}}{1+\mathrm{d}}\right)^{\mathrm{N}_{\mathrm{T}}}\right]
$$

where, $\mathrm{D}$ is interest rate.

The cost of energy recovered by heat pipe condenser, $\mathrm{C}_{\mathrm{E}}$ can be defined as follow:

$$
\mathrm{C}_{\mathrm{E}}=\frac{\text { Price of diesel }\left(\text { Baht L }^{-1}\right)\left(3.6 \times 10^{6}\right)}{(\mathrm{HHV})\left(\rho_{\text {diesel }}\right)}
$$

Where:

HHV $=$ High heating value of diesel $\left(\mathrm{J} \mathrm{kg}^{-1}\right)$

$\rho_{\text {diesel }}=$ Density of diesel $\left(\mathrm{kg} \mathrm{m}^{-3}\right)$

$\mathrm{H}$ and $\dot{\mathrm{Q}}$ are the annual time of operation and the heat recovered by CLOHP, respectively. In this study, $\dot{\mathrm{Q}}$ is assumed and equal to $\dot{\mathrm{Q}}_{\mathrm{c}}$ as:

$\dot{\mathrm{Q}}=\dot{\mathrm{Q}}_{\mathrm{c}}=\dot{\mathrm{q}} \mathrm{A}_{\mathrm{e}}$

Where $\dot{q}$ and $A_{e}$ are heat flux and the evaporator section area of CLOHP are presented by Khandekar et al. (2003) and can be calculated from Eq. 15 and 16:

$$
\dot{\mathrm{q}}=0.54\{\exp (\beta)\}^{0.48} \mathrm{Ka}^{0.47} \operatorname{Pr}_{\text {liq }}^{0.27} \mathrm{Ja}^{1.43} \mathrm{~N}^{-27}
$$

Where:

$\beta=$ Inclination angle from horizontal axis of heat pipe heat exchanger (rad)

$\mathrm{Ka}=$ Karman number

$\operatorname{Pr}=$ Prandtl number

$\mathrm{Ja}=$ Jakob number

$\mathrm{N}=$ Number of turn of CLOHP

$$
\mathrm{A}_{\mathrm{e}}=2 \pi \mathrm{D}_{\mathrm{i}} \mathrm{L}_{\mathrm{e}} \mathrm{N}
$$

Where:

$\mathrm{D}_{\mathrm{i}}=$ Inner diameter of heat pipe $(\mathrm{m})$

$\mathrm{L}_{\mathrm{e}}=$ Evaporator section length of CLOHP $(\mathrm{m})$

When Eq. 15 and 16 are substituted in (14) and Q is calculated from condenser model, therefore, the $\mathrm{N}$ can be computed in Eq. 17:

$$
\mathrm{N}=\frac{\dot{\mathrm{Q}}}{\left(2 \pi \mathrm{D}_{\mathrm{i}} \mathrm{L}_{\mathrm{e}}\right)\left[0.54\{\exp (\beta)\}^{0.48} \mathrm{Ka}^{0.47} \mathrm{Pr}_{\mathrm{liq}}^{0.27} \mathrm{Ja}^{1.43}\right]}
$$

$\mathrm{P}_{2}$ in the Eq. 10 is the economic factor and defined in Eq. 18:

$$
\mathrm{P}_{2}=1+\mathrm{P}_{1} \mathrm{M}_{\mathrm{s}}-\mathrm{R}_{\mathrm{v}}(1+\mathrm{d})^{-\mathrm{N}_{\mathrm{T}}}
$$

Where:

$\mathrm{M}_{\mathrm{s}}=$ Ratio of annual maintenance and operation cost into first original cost

$R_{v}=$ Ratio of resale value into first original cost

The first cost depended on three factors i.e., tube cost, Working Fluid (WF) cost and cost of casing. They are presented in Eq. 19-21:

Tube cost $=($ Tube price $/$ meter $) \times\left(2 \mathrm{~L}_{\mathrm{t}} \mathrm{N}\right)$

WF cost $=\left(\right.$ WFprice $\left./ \mathrm{m}^{3}\right) \times\left(0.5 \pi \mathrm{D}_{\mathrm{i}} \mathrm{L}_{\mathrm{t}} \mathrm{N}\right)$

Cost of casing $=($ Case price $/$ turn $) \times(\mathrm{N})$

Where:

$\mathrm{Lt}=$ Total length of heat pipe $(\mathrm{m})=\mathrm{L}_{\mathrm{e}}+\mathrm{L}_{\mathrm{a}}+\mathrm{L}_{\mathrm{c}}$ $\mathrm{L}_{\mathrm{a}}=$ Adiabatic section length of heat pipe $(\mathrm{m})$

$\mathrm{L}_{\mathrm{c}}=$ Condenser section length of heat pipe $(\mathrm{m})$

Flow chart of the conventional refrigeration simulation: From the previous equations, the flow chart to simulate various parameters of the conventional refrigeration system can be shown as in Fig. 4. The controlled parameters are fixed as follow:

$$
\begin{aligned}
\mathrm{T}_{\text {sup }} & =10^{\circ} \mathrm{C} \\
\mathrm{T}_{\text {sub }} & =0^{\circ} \mathrm{C} \\
\mathrm{T}_{1} & =5^{\circ} \mathrm{C} \\
\dot{\mathrm{Q}}_{\mathrm{e}} & =3663 \mathrm{~W} \\
\mathrm{~V}_{\mathrm{P}} & =0.0000305 \mathrm{~m}^{3} \mathrm{sec}^{-1} \\
\mathrm{~N}_{\text {comp }} & =47.5 \mathrm{rps} \\
\mathrm{L}_{\text {cap }} & =0.8 \mathrm{~m} \\
\mathrm{D}_{\text {cap }} & =0.001397 \mathrm{~m} \\
\mathrm{~N}_{\text {cap }} & =2 \\
\Delta \mathrm{P}_{\mathrm{c}} & =68.95 \mathrm{kPa}
\end{aligned}
$$

Then, the condensing Temperature $\left(\mathrm{T}_{\mathrm{c}}\right)$ is initially assumed to be slightly higher than the ambient temperature. Then, the evaporating temperature is calculated. Next, the program determines the refrigerant's properties from R22's subroutine. The refrigerant mass flow rate $\left(\dot{\mathrm{m}}_{\text {ref }}\right)$ is calculated by compressor model and compare with the refrigerant mass flow rate $\left(\dot{\mathrm{m}}_{\text {ref,cap }}\right)$ which is calculated from the capillary tube model. If they do not agree within an 
Energy Rec. J. 1 (2): 104-110, 2010

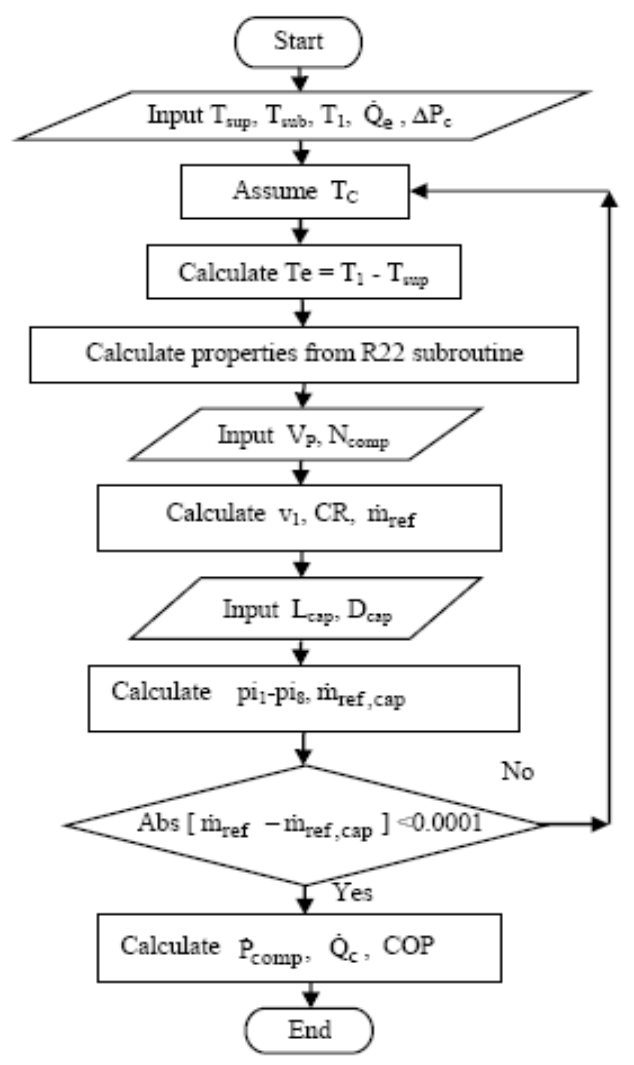

Fig. 4: The Flow chart of the conventional refrigeration simulation

acceptable tolerance, the $T_{c}$, as well as the refrigerant mass flow rate will be re-iterated until the agreement between $\dot{\mathrm{m}}_{\text {ref }}$ and $\dot{\mathrm{m}}_{\text {ref, ,ap }}$ is established. Finally, $\dot{\mathrm{P}}_{\text {comp }}$, $\dot{\mathrm{Q}}_{\mathrm{c}}$ and COP are calculated.

Flow chart of the net saving simulation: Procedure of flow chart for the net saving simulation to predict optimum sizing of the closed loop pulsating heat pipe condenser by using thermo-economical method is shown in Fig. 5. The simulation program is started with the controlled and variable parameters as follow:

$$
\begin{array}{ll}
\mathrm{T}_{\mathrm{hi}} & =\mathrm{T}_{2}(\text { Compressor outlet temperature) } \\
\mathrm{T}_{\mathrm{ci}} & =\text { Coolant fluid temperature (water) } \approx 20^{\circ} \mathrm{C} \\
\mathrm{L}_{\mathrm{a}} & =0.0030 \mathrm{~m} \\
\dot{\mathrm{Q}}_{=} \dot{\mathrm{Q}}_{\mathrm{c}} & =4,837 \mathrm{~W} \\
\beta & =1.57 \mathrm{rad}^{-1} \\
\mathrm{H} & =2,920 \mathrm{~h} \mathrm{year}^{-1} \\
\mathrm{i} & =0.04 \\
\mathrm{~d} & =0.016 \\
\mathrm{~N} & =10 \text { years }
\end{array}
$$

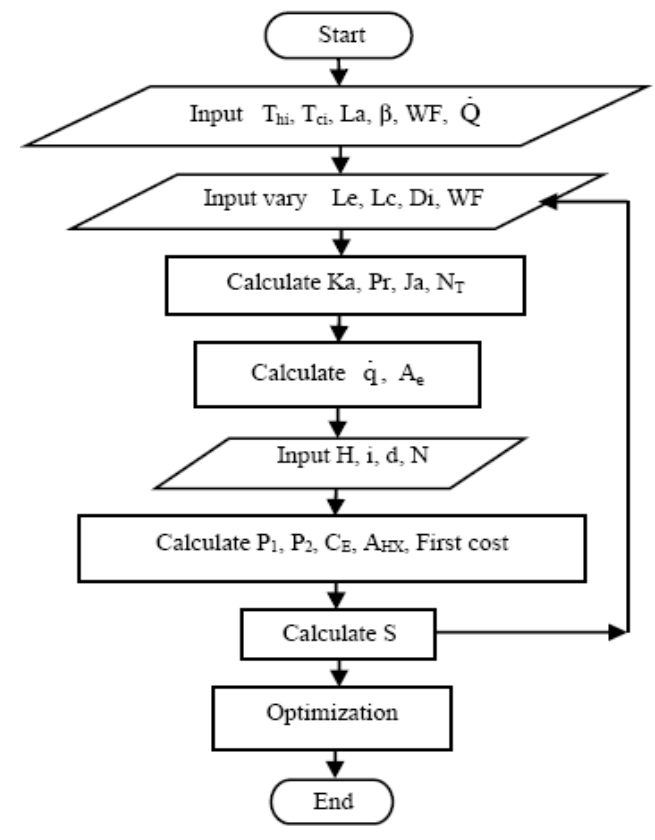

Fig. 5: Flow chart of the net saving simulation

$$
\begin{aligned}
\mathrm{WF}= & \mathrm{R} 123, \text { water, ethanol } \\
\mathrm{L}_{\mathrm{e}}= & 0.010 .020 .03 \ldots 0.1 \mathrm{~m} \\
\mathrm{~L}_{\mathrm{c}}= & 0.10 .110 .12 \ldots 0.15 \mathrm{~m} \\
\mathrm{D}_{\mathrm{i}}= & 0.00091, \quad 0.00106,0.00127,0.0014,0.0015, \\
& 0.00163,0.00178,0.00191,0.00203 \mathrm{~m}
\end{aligned}
$$

Then, the evaporator section Length $\left(\mathrm{L}_{\mathrm{e}}\right)$, the condenser section Length $\left(\mathrm{L}_{\mathrm{c}}\right)$, the inner Diameter $\left(\mathrm{D}_{\mathrm{i}}\right)$ and the WF are initially varied and the Ka, Pr and Ja are calculated. Since the heat rejection at the conventional condenser is obtained by simulation program in Fig. 4, therefore, the number of turn is determined by Eq. 17 . Next, the heat flux $(\dot{\mathrm{q}})$ and the evaporator section area of CLOHP $\left(\mathrm{A}_{\mathrm{e}}\right)$ are calculated by Eq. 15 and 16 respectively.

The net saving (S) will be calculated by Eq. 10 and then, the $L_{e}, L_{c}$ and $D_{i}$ will be changed to next value. Next, the $S$ will be recalculated until they are acceptable. Finally, the optimum sizing of CLOHP is considered with the maximum net saving for the suitable refrigeration system.

\section{RESULTS}

Simulation result of the conventional refrigeration: The results of the conventional refrigeration system obtained by the simulation procedure in Fig. 4 were $\mathrm{T}_{\mathrm{c}}=60^{\circ} \mathrm{C}, \quad \dot{\mathrm{m}}_{\mathrm{ref}}=0.031 \mathrm{~kg} \quad \mathrm{sec}^{-1}, \quad \mathrm{~T}_{2}=85^{\circ} \mathrm{C}$, $\dot{\mathrm{P}}_{\text {comp }}=1,174 \mathrm{~W}, \dot{\mathrm{Q}}_{\mathrm{c}}=4,837 \mathrm{~W}$ and COP $=3.1$. This $\dot{\mathrm{Q}}_{\mathrm{c}}$ will be assumed to be equal to the $\dot{\mathrm{Q}}$ in Eq. 10 . 
Energy Rec. J. 1 (2): 104-110, 2010

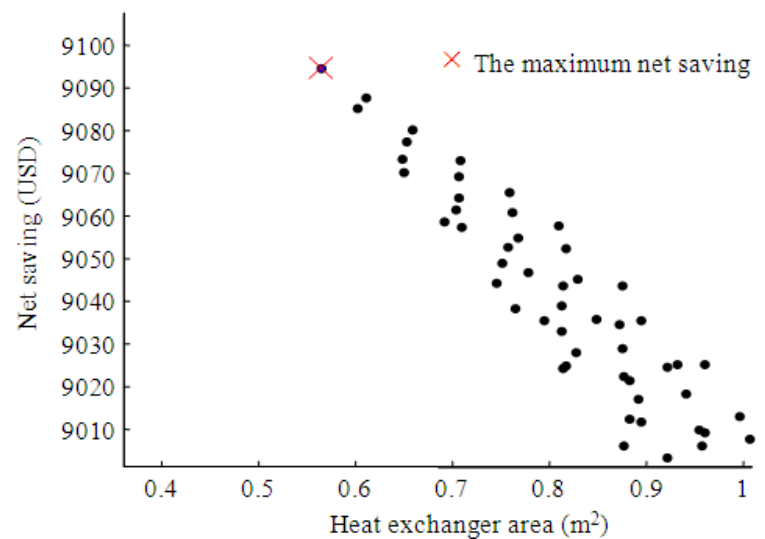

Fig. 6: The effect of heat exchanger area on the net saving at $\mathrm{Q}=4,837 \mathrm{~W}$ of $\mathrm{R} 123$

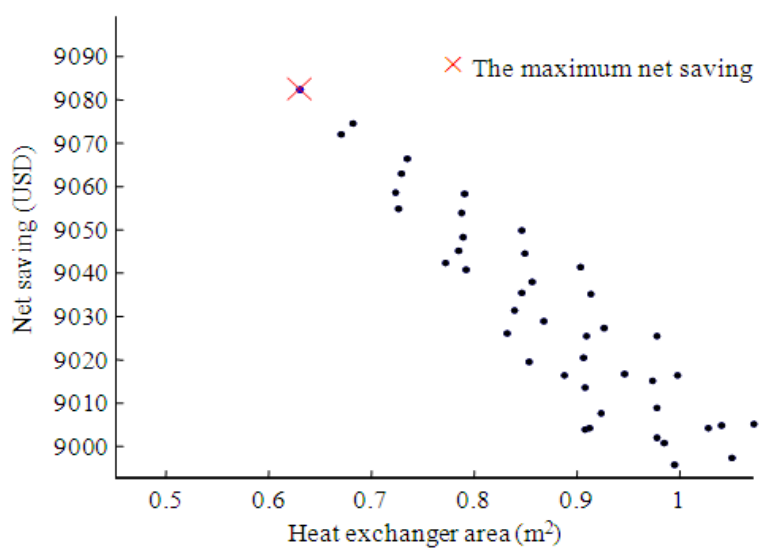

Fig. 7: Effect of heat exchanger area on the net saving at $\mathrm{Q}=4,837 \mathrm{~W}$ of ethanol

The effect of heat exchanger area on the net saving: The our in-situ experimental data of refrigerating capacity was 3,633 Watt. From this point, the heat rejection at condenser $\left(\dot{Q}_{c}\right)$ which was simulated from the procedure in Fig. 4 is 4,837 Watt. Therefore, the following section will be simulated according to this condition. The result of system with R123 is shown in Fig. 6.

Figure 6 shows the effect of heat exchanger area on the net saving at $\mathrm{Q}=4,837 \mathrm{~W}$ of $\mathrm{R} 123$. The maximum of net saving is $9,095 \mathrm{USD}$, heat exchanger area is $0.56 \mathrm{~m}^{2}$, the number of turn is 218 turns, $\mathrm{L}_{\mathrm{e}}=0.1 \mathrm{~m}$, $\mathrm{L}_{\mathrm{c}}=0.1 \mathrm{~m}, \mathrm{D}_{\mathrm{i}}=0.00203 \mathrm{~m}$, the heat pipe condenser should be designed at this parameters. The minimum heat exchanger area is found to be $0.56 \mathrm{~m}^{2}$, but the maximum of net saving is not necessarily exits at the minimum heat exchanger area.
Figure 7 shows the effect of heat exchanger area on the net saving at $\mathrm{Q}=4,837 \mathrm{~W}$ of the system with ethanol as working fluid. The maximum of net saving is $9,082 \mathrm{USD}$, heat exchanger area is $0.63 \mathrm{~m}^{2}$, the number of turn is 243 turns, $\mathrm{L}_{\mathrm{e}}=0.1 \mathrm{~m}, \mathrm{~L}_{\mathrm{c}}=0.1 \mathrm{~m}$, $D_{i}=0.00203 \mathrm{~m}$. The minimum heat exchanger area is $0.63 \mathrm{~m}^{2}$.

Figure 8 shows the effect of heat exchanger area on the net saving, at $\mathrm{Q}=4,837 \mathrm{~W}$ of the system with water as working fluid. The maximum of net saving is 9,117 USD, heat exchanger area is $0.45 \mathrm{~m}^{2}$, the number of turn is 176 turns, $\mathrm{L}_{\mathrm{e}}=0.1 \mathrm{~m}, \mathrm{~L}_{\mathrm{c}}=0.1 \mathrm{~m}, \mathrm{D}_{\mathrm{i}}=0.00203 \mathrm{~m}$. The minimum heat exchanger area is $0.45 \mathrm{~m}^{2}$.

\section{DISCUSSION}

Figure 6 shows the effect of heat exchanger area on the net saving in practical condition can be observed. At $\mathrm{Q}=4,837 \mathrm{~W}$ of system with $\mathrm{R} 123$, it can be shown that the net saving decreases as the heat exchanger area increases. Therefore, in this case, when consider in Eq. 10 , it was found that the heat exchanger area increases, resulting in the higher increase in the first cost than that of waste heat recovery.

Figure 7 shows the effect of heat exchanger area on the net saving at $\mathrm{Q}=4,837 \mathrm{~W}$ of the system with ethanol as working fluid. The trend is similar to those in Fig. 6 that is the net saving decreases as the heat exchanger area increases. It can be seen that the maximum of net saving of ethanol as a working fluid lower than those of R123 system.

Figure 8 shows the effect of heat exchanger area on the net saving, at $\mathrm{Q}=4,837 \mathrm{~W}$ of the system with water as working fluid. The trend is similar to those in Fig. 6 and 7. The net saving decreases as the heat exchanger area increases. When all working fluids are compared, it can be seen that the maximum of net saving can be obtained in case the system with water as a working fluid.

The optimum sizing of the CLOHP condenser: When all working fluids are considered, it can be seen that the maximum net saving can be obtained in case the system with water as a working fluid. This is because, the water has higher Jacob number (Ja), resulting in the high heat flux $(\dot{\mathrm{q}})$. The CLOHP with the high heat flux has generally small heat exchanger area as shown in Eq. 14, therefore, it will has high net saving. For this study, the system with water as a working fluid is suitable and the optimum $\mathrm{A}_{\mathrm{HE}}, \mathrm{N}, \mathrm{L}_{\mathrm{e}}, \mathrm{L}_{\mathrm{c}}$ and $\mathrm{D}_{\mathrm{i}}$ are $0.45 \mathrm{~m}^{2}, 176$ turns, $0.1,0.1$ and $0.00203 \mathrm{~m}$, respectively. 


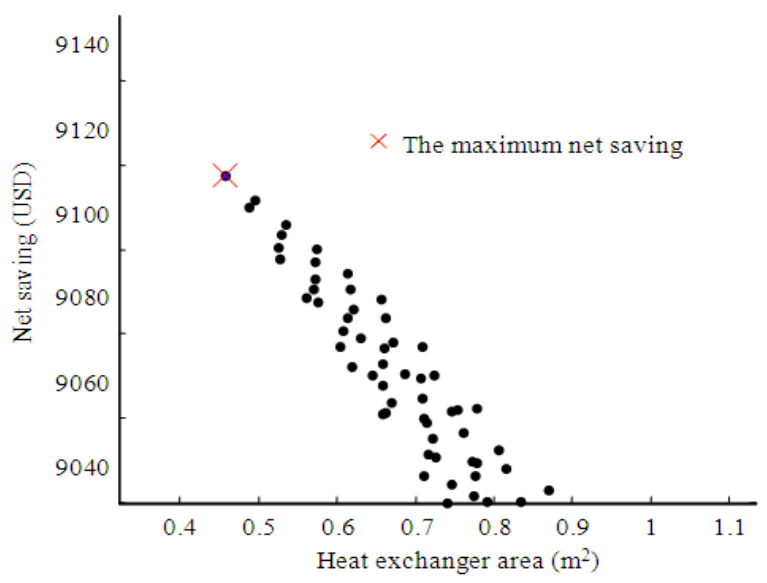

Fig. 8: Effect of heat exchanger area on the net saving at $\mathrm{Q}=4,837 \mathrm{~W}$ of water

\section{CONCLUSION}

The simulation program to determine the optimum CLOHP to be applied as a condenser in the conventional refrigeration system has been established. Results from the simulation program with the controlled parameter of $\mathrm{T}_{\mathrm{c}}=60^{\circ} \mathrm{C}, \quad \dot{\mathrm{m}}_{\text {ref }}=0.31 \mathrm{~kg}$ $\sec ^{-1}$ are; $\mathrm{T}_{2}=85^{\circ} \mathrm{C}, \dot{\mathrm{P}}_{\text {comp }}=1,174 \mathrm{~W}, \dot{\mathrm{Q}}_{\mathrm{c}}=4,837 \mathrm{~W}$ and $\mathrm{COP}=3.1$. For the simulation of net saving, it can be concluded that, as heat exchanger area increases, the net saving drastically decreases. The maximum net saving of all working fluids is determined at the minimum heat exchanger area. At the controlled $\mathrm{Q}$ of $4,837 \mathrm{~W}$, it can be seen that, the maximum of net saving occurs with the system with water as a working fluid as 9,117 USD. The optimum $\mathrm{A}_{\mathrm{HE}}, \mathrm{N}, \mathrm{L}_{\mathrm{e}}, \mathrm{L}_{\mathrm{c}}$ and $\mathrm{D}_{\mathrm{i}}$ are $0.45 \mathrm{~m}^{2}, 176$ turns, $0.1,0.1$ and $0.00203 \mathrm{~m}$, respectively. The pressure drop that occurs in the CLOHP condenser will be our work in future.

\section{ACKNOWLEDGEMENT}

This research was conducted under the support of the Science and Technology Ministry of Thailand, Rajamangala University of Technology Lanna (RMUTL) and Chiag Mai University.

\section{REFERENCES}

ASHRAE., 1997. Handbook Fundamental. ASHRAE, ISBN: 1-883413-45-1, USA.

Cabello, R., J. Navarro and E. Torrella, 2004. Simplified steady-state modeling of single stage vapour compression plant. Model development and validation. Applied thermal engineering., Applied Therm. Eng., 25: 1740-1752.
Chan, K.T. and F.W. Yu, 2002. Parameterization staudy on the operating efficiency of air-cooled chillers. Adv. Build. Technol., 2: 1157-1164.

Charoensawan, P., P. Terdtoon, P. Tantakom and P. Ingsuwan, 2003. Effect of evaporator section lengths, number of turns and working fluid on internal flow patterns of a vertical closed-loop oscillating heat pipe. Proceeding of the 7th International Heat Pipe Symposium, Sept. 2003, Jeju Korea, pp: 360-367.

Charoensawan, P., S. Khandekar, M. Groll and P. Terdtoon, 2003. Closed loop pulsating heat pipe part A: Parametric experimental investigations. Applied Therm. Eng., 23: 2009-2027.

Jameel-Ur-Rehman Khan and S.M. Zubair, 1998. Design and performance evaluation of reciprocating refrigeration system. Int. J. Refriger., pp: 235-243.

Kammuang-Lue, N., P. Sakulchangsajatai, T. Waowaew and P. Terdtoon, 2006. Effect of working fluid types on thermal effectiveness of closed-loop pulsating heat pipe on ice storage system. Proceeding of the 8th International Heat Pipe Symposium, Kumamoto, Japan.

Khandekar, S., P. Charoensawan, M. Groll and P. Terdtoon, 2003. Closed loop pulsating heat pipes part B: Visualization and semi-empirical modeling. Applied Therm. Eng., 23: 2021-2033.

Meena, P., S. Rittidech and N. Poomsa-Ad, 2007. Closed-Loop Oscillating Heat-Pipe with Check Valves (CLHPCVs) air-preheater for reducing relative humidty in drying systems. Applied Energy, 84: 363-373.

Shiming, D. and H. Han, 2004. An experimental study on clothes drying using rejected heat with splittype residential air conditioners. Applied Therm. Eng., 24: 2789-2800.

Soylemez, M.S., 2000. On the optimum heat exchanger sizing for heat recovery. Energy Manage., 41: 1419-1427.

Soylemez, M.S., 2003. On the thermoeconomical optimization of Heat Pipe Heat Exchanger HPHE for waste heat recovery. Energy Manage., 44: 2509-2517.

Soylemez, M.S., 2004. On the thermoeconomical optimization of single stage refrigeration systems. Energy Build., 3: 965-968.

Techarungpaisan, P., S. Theerakulpisut and S. Priprem, 2007. Modeling of split type air conditioner with integrated water heater. Energy Convers. Manage., 48: 1222-1237.

Wilbert, F. Stoecker and Jerold W. Jones, 1982. Refrigeration and air Conditioning. McGraw-Hill Int., Singapore, 2nd Edn., pp: 443. 